\title{
Fruit set of distylous Psychotria carthagenensis Jacq. (Rubiaceae) mediated by Apis mellifera (Apidae) and species of Augochloropsis (Halictidae)
}

Rogério Rodrigues Faria ${ }^{1 *}$ and Andréa Cardoso Araujo ${ }^{2}$

Received: January 12, 2015 Accepted: February 22, 2015

\begin{abstract}
Heterostyly is a floral polymorphism consisting in the presence of two morphs in the population that differ reciprocally in the position of their sexual organs. Heterostylous species depend on visitors to produce fruits, but the efficiency of insect species as pollinators greatly varies and depends on the morph visited. The aim of the present study was to determine the effect of a single visit by the bees Apis mellifera and species of Augochloropsis on the fruit set of the distylous species Psychotria carthagenensis. After a single visit from each bee species, flowers were bagged to monitor the fruit set. Pollination effectiveness between pollinators and morphs was compared. The results of the experiments were compared with data from manual intermorph cross-pollination using the $\mathrm{G}$ test. There were no significant differences in the fruit set between treatments (insect visit and cross-pollination), and between flowers visited by Augochloropsis spp. and flowers visited by A. mellifera. Our results suggest that pollination effectiveness of the studied bees was not related to floral morph, and that both exotic and native bees showed similar performances on the fruit set of P. carthagenensis.
\end{abstract}

Keywords: Bee pollination, heterostyly, honeybees, pollination effectiveness, reproductive success

Distyly is a floral dimorphism characterized by the presence of two floral morphs that differ reciprocally in the heights of stigmas and anthers in flowers. Distyly is usually accompanied by a heteromorphic incompatibility system and a set of morphological characters that differ between the two morphs, called ancillary characters (Ganders 1979; Barrett 1992; Dulberger 1992). The position of sex organs in flowers pollinated by animals plays an important role in the dispersion of pollen to co-specific stigmas (Thompson et al. 2003). Among heterostylous species that lack a heteromorphic incompatibility system, morphological differences between morphs particularly exert a strong influence over breeding patterns between individuals (Barrett et al. 2004). In heterostylous species, reciprocal herkogamy is expected to promote intermorph pollination through deposition of pollen from different morphs in separate parts of the pollinators' body (Lloyd \& Webb 1992; Ornelas et al. 2004; Massinga et al. 2005).

The effectiveness of a pollinator is determined by its contribution to the fitness of a plant in terms of both qualitative and quantitative components (Herrera 1987, 1989; Moragues \& Traveset 2005). Methods of effectiveness measurement include the analysis of its visiting behavior and frequency, the amount of pollen transported, pollen deposition rate on the stigma of the conspecific flower, the growth success of the pollen tube, the fertilization success of the ovules in the ovary (Gross 2005), and finally, the fruit set, which is the success of fruit formation (Ivey et al. 2003). Data on different species of pollinator are important to analyze the degree of specialization of the plant and to infer the role of each visitor on the reproductive success of a given plant species (Stebbins 1970; Fumero-Cabán \& Meléndez-Ackerman 2007).

The role of each floral visitor is defined by the result of its interaction with a given plant species (Freitas 2014). The interactions, including those of exotic visitors, can become even more complex, and depending on the situation, consequences could be as follows: (1) negative, if resulting in competition with native pollinators (see Paini 2004), or in failure to deposit pollen on the anthers of native plant species (see Huryn 1997), and if changing the structure of mutualistic networks (e.g., Santos et al. 2012; Aizen et al. 2014); (2) positive, through effective pollination (see Huryn 1997) and if resulting in the establishment of new effective interactions (Olesen et al. 2002); and (3) neutral

\footnotetext{
${ }^{1}$ Programa de Pós-Graduação em Ecologia e Conservação, Universidade Federal de Mato Grosso do Sul, PO Box 549, 79070-900, Campo Grande, MS, Brazil ${ }^{2}$ Centro de Ciências Biológicas e da Saúde, Universidade Federal de Mato Grosso do Sul, PO Box 549, 79070-900, Campo Grande, MS, Brazil

* Corresponding author: Current address - Universidade Federal de Mato Grosso do Sul, Campus de Aquidauana. Oscar Trindade de Barros, 740, 79200-000, Aquidauana, MS, Brazil roger.faria@yahoo.com.br
} 
(Paini 2004). Therefore, to better understand these plantpollinator interactions in a broader view, it is important to investigate them in a more specific manner.

Previous work in the studied populations showed that Psychotria carthagenensis Jacq. (Rubiaceae) is self-compatible, has a high degree of reciprocity between morphs, and an equal morph ratio in the populations (Faria et al. 2012). According to results of controlled hand pollinations in these populations, fruit set ranged from 5 to $35 \%$ in self-pollinations for short-styled (S) flowers and from 20 to $45 \%$ in long-styled (L) flowers. For intermorph crosses, it varied between $15 \%$ and $20 \%$ in S-flowers and $15 \%$ and $25 \%$ in L-flowers (Faria et al. 2012). This sub-forest shrub is two to three meters tall and is distributed from Costa Rica to Argentina (Delpetre et al. 2005). In Brazil, these plants are commonly found in areas of moist soil in the proximity of water bodies, both in the Pantanal wetland and savanna regions (Pott \& Pott 1994; Felfili et al. 2001).

The objective of this study was to evaluate the efficiency of the two more common pollinators of $P$. carthagenensis on the plant's female reproductive success. For this, we allowed one single visit of Apis mellifera Linnaeus, 1758 or Augochloropsis Cockerell, 1897 spp. to L-flowers and S-flowers in three different populations of $P$. carthagenensis and then compared the fruit set.

The three populations of $P$. carthagenensis analyzed in this study occur in savanna fragments in protected areas located within an urban matrix in the municipality of Campo Grande, state of Mato Grosso do Sul, Brazil. These three areas are separated from each other by a mean distance of $12.45 \mathrm{~km}$ : Prosa State Park (PSP 135 ha, $20^{\circ} 27^{\prime} 00^{\prime \prime}$ S, $54^{\circ} 33^{\prime} 46^{\prime \prime}$ W), Reserve of the Universidade Federal de Mato

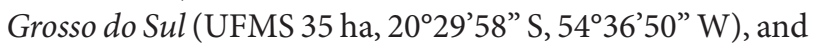
Reserve of the Empresa Brasileira de Pesquisa Agropecuária (EMBRAPA 175 ha, $20^{\circ} 25^{\prime} 41^{\prime \prime} \mathrm{S}, 54^{\circ} 43^{\prime} 03^{\prime \prime} \mathrm{W}$ ). In all three areas, $P$. carthagenensis occurs on moist soils. The climate in the region is tropical savanna (Aw cf. Köppen 1948), characterized by a pronounced dry season from May to September and a rainy season from October to April. Annual accumulated rainfall is approximately $1532 \mathrm{~mm}$ and mean annual temperature is $20-22^{\circ} \mathrm{C}$ (EMBRAPA-CNPGC 1985). This experiment was conducted during the blooming season of 2009 (November and December) when, in the study areas, P. carthagenensis has a strong floral display in comparison with other low-stratum species (Faria RR, "personal obs.").

Flowers of both morphs of $P$. carthagenensis open between $0500 \mathrm{~h}$ and $0600 \mathrm{~h}$. At this time, the lobes of the corolla are completely separated and perpendicularly positioned in relation to the floral axis, with the reproductive structures exposed. Floral senescence occurs between $1700 \mathrm{~h}$ and $1800 \mathrm{~h}$ on the same day (see Faria et al. 2012 for more details on the floral biology of the species).

Fruit production was calculated after one single visit of different pollinators, including Apis mellifera and several species of Augochloropsis. Augochloropsis spp. is considered herein as a single treatment, but may actually be more than one species, as the identification of this group on the species level through visual observation alone is difficult. However, all individuals of this bee species exhibited the same behavior during all visits. In the three populations, 10 plants of each floral morph were selected, and in each one, we marked three buds for the experiments (totaling 30 flowers). The plants and buds were chosen at random in all populations, according to their availability. Emasculated P. carthagenensis buds were isolated with nylon bags in the pre-anthesis phase and marked with a black cotton line. Emasculation of buds is necessary because studied populations are self-compatible and agamospermy was found in L-morphs (Faria et al. 2012). The desired number of flowers $(N=30)$ was reached for Augochloropsis spp. only at EMBRAPA. For this reason, in the UFMS and PSP populations, the experiment was only conducted with $A$. mellifera. We monitored 20 plants in UFMS, 20 plants in PSP, and 40 plants in EMBRAPA. During early anthesis, when the flowers were open and receptive, the bags were removed to await the visit from the pollinator of interest (Augochloropsis spp. or Apis mellifera). After the visit and departure of the pollinator, the flower was bagged again for the subsequent determination of fruit production.

Fruit set (number of fruits produced divided per number of flowers treated) after one visit of the two species of pollinators was compared with that obtained for flowers manually cross-pollinated in the same populations. We calculated the average fruit set for each plant. In the xenogamy treatment, the manual deposition of pollen (from the flower of a different morph) was performed on the receptive stigma of virgin, emasculated flowers. After handling, the flowers were bagged again for the subsequent determination of fruit production. Twenty flowers per morph, each from a different individual, were treated, totaling forty replicates for each population (Faria et al. 2012). The comparison between the fruit set following the visit from the bees and that obtained with xenogamy was performed on the basis of the premise that xenogamy would represent the maximal pollination limit (Sobrevilla \& Arroyo 1982). To test for differences among treatments a G-test with an alpha level of 0.05 was performed (Sokal \& Rolf 1995).

When visiting the flowers of $P$. carthagenensis, both Apis mellifera and Augochloropsis spp. introduce the anterior part of the body into the corolla. The former introduces its head and the latter introduces its head and thorax.

Fruit set from xenogamy treatment at PSP was 20\% in both floral morphs; in the UFMS population it was $20 \%$ in S-flowers and 15\% in L-flowers and at EMBRAPA it was 15\% in S-flowers and 25\% in L-flowers (Faria et al. 2012). After a single visit from Apis mellifera, the fruit set ranged from 10 to $33 \%$, and after a single visit from Augochloropsis spp., the fruit set was 27\% in S-flowers and 30\% in L-flowers (Fig. 1).

In both morphs, no significant differences in the fruit set were observed in any of the populations when comparing flowers from the xenogamy treatment and those visited 
by either Apis mellifera or Augochloropsis spp. (Tab. 1). Moreover, no significant differences in the fruit set were observed in the comparison between the flowers visited by Augochloropsis spp. and flowers visited by $A$. mellifera in the EMBRAPA population $(G=1.71 ; \mathrm{df}=1 ; P=0.191)$.

On the basis of the results of the present study, a single visit from Apis mellifera to $P$. carthagenensis flowers under natural conditions is sufficient in promoting fruit set in both floral morphs. In addition, in populations where both Apis mellifera and Augochloropsis spp. were analyzed, they achieved similar effects on the pollination of $P$. carthagenensis.

In all experiments, fruit set was never higher than 33\%, which agrees with the results obtained in another study in the same areas and probably indicates resource limitation, abortion, or inbreeding depression (Faria et al. 2012). Apis mellifera was effective in promoting the fruit set in all populations of $P$. carthagenensis. Augochloropsis spp. presented similar results in the EMBRAPA population. Because of adaptive features, which lead to differences in the quality and quantity of pollen deposited on the stigmas of native plant species, one may expect differences in pollination effectiveness between exotic and native pollinators (Goulson 2003; Kenta et al. 2007; Madjidian et al. 2008), which supposedly evolved together with the plant species

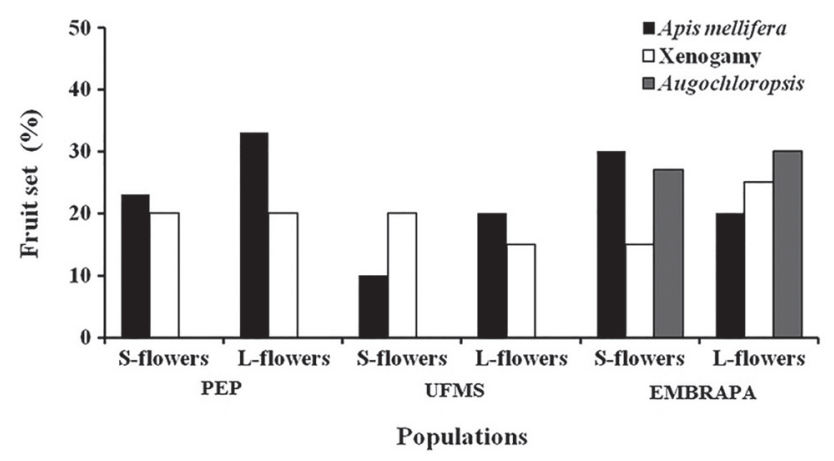

Figure 1. Fruit set (\%) after single visits of Apis mellifera and Augochloropsis spp. to flowers of Psychotria carthagenensis and after xenogamy pollination treatment for the studied populations (PSP = Prosa State Park, UFMS = Reserve of the Universidade Federal de Mato Grosso do Sul, EMBRAPA = Reserve of the Empresa Brasileira de Pesquisa Agropecuária) at Campo Grande, MS, Brazil. (S-flowers $=$ short-styled flowers, L-flowers $=$ long-styled flowers $)$. of a given site. Results presented here should be considered with caution, because fruit set was the only parameter evaluated as a measure of pollination effectiveness. In addition, comparisons of pollination efficiencies between both native and exotic pollinator species were only possible for one of the studied populations. Further studies are needed to clarify these issues by addressing other components of pollination effectiveness, such as the population dynamics of the pollinating species as well as differences in pollinator species on plant male function.

Apis mellifera is reported to be an important pollinator of a number of native species (Dick 2001; Nadia et al. 2007), although some studies have demonstrated that this bee can reduce the reproductive success of the plants it visits (Gross \& Mackay 1998; Carmo et al. 2004). It is difficult to draw conclusions regarding the impact of this exotic species on communities of native bees, as there are no previous studies on the interaction between native bees and plants prior to the introduction of Apis mellifera in Brazil (Wilms et al. 1996).

On the basis of the comparison with results from the xenogamy experiment, a single visit from the bees was sufficient to promote fruit set in the studied populations. Since P. carthagenensis flowers last only one day, the effectiveness of visitors in one visit is extremely important, ensuring its pollination.

In the population where both Apis mellifera and Augochloropsis spp. where analyzed, they achieved similar results in the pollination of $P$. carthagenensis. It is therefore possible that the origin of the pollen grains deposited on the stigmas by Apis mellifera and Augochloropsis spp. is a combination of autogamous, intramorph, and intermorph pollinations.

Our results suggest that pollination effectiveness of the studied bees was not related to floral morph, and that both exotic and native bees showed similar performances on the fruit set of $P$. carthagenensis. However, these findings must be viewed with caution because of the small number of studied populations, and because we have focused on only one measure of pollination effectiveness. Since several components are involved in the performance of different floral visitors in the pollination of a given plant species (Freitas 2014), additional studies investigating the relative

Table 1. Results for the statistical analysis comparing fruit set between treatments (bee species and xenogamy) for the populations of Psychotria carthagenensis studied at Campo Grande, MS, Brazil.

\begin{tabular}{|c|c|c|c|c|c|c|c|}
\hline \multirow[b]{2}{*}{ Population $^{1}$} & \multirow[b]{2}{*}{ Morph } & \multicolumn{3}{|c|}{ A. mellifera vs. Xenogamy } & \multicolumn{3}{|c|}{ Augochloropsis spp vs. Xenogamy } \\
\hline & & G-value & Df & $\mathbf{P}$ & G-value & Df & $\mathbf{P}$ \\
\hline \multirow[t]{2}{*}{ PSP } & $\mathrm{L}$ & 1.088 & 1 & 0.30 & - & - & - \\
\hline & S & 0.078 & 1 & 0.78 & - & - & - \\
\hline \multirow[t]{2}{*}{ UFMS } & $\mathrm{L}$ & 0.207 & 1 & 0.65 & - & - & - \\
\hline & S & 0.975 & 1 & 0.32 & - & - & - \\
\hline \multirow[t]{2}{*}{ EMBRAPA } & $\mathrm{L}$ & 0.173 & 1 & 0.68 & 0.150 & 1 & 0.70 \\
\hline & S & 1.548 & 1 & 0.21 & 0.988 & 1 & 0.32 \\
\hline
\end{tabular}

${ }^{1}$ PSP = Prosa State Park, UFMS = Reserve of the Universidade Federal de Mato Grosso do Sul, EMBRAPA = Reserve of the Empresa Brasileira de Pesquisa Agropecuária Morph: $\mathrm{L}=$ long-styled, $\mathrm{S}=$ short-styled

Df: degrees of freedom

$P$ : significance value 
roles of different visitors, more specifically comparing efficiencies of exotic and native pollen vectors, are necessary for better understanding the reproductive ecology of P. carthagenensis.

\section{Acknowledgments}

The authors are grateful to V.J. Pott for plant identification; to P. Menezes and V.A. Laura for logistical support in the PSP and EMBRAPA reserves, respectively; to C.C. Castro, M.R. Sigrist, A.P.L. Lemke and two anonymous referees for helpful comments; to L. Navarro for comments on prior drafts of the manuscript; and to the Brazilian fostering agencies FUNDECT/CAPES for the doctoral grant awarded to R.R. Faria $(41 / 100.271 / 2006)$ and to FUNDECT for financial support (23/200.288/2008).

\section{References}

Aizen MA, Morales CL, Vazquez DPV, Garibaldi LA, Sáez A, Hardler LD. 2014. When mutualism goes bad: density-dependent impacts of introduced bees on plant reproduction. New Phytologist 204: 322-328.

Barrett SCH. 1992. Heterostylous genetic polymorphisms: Model systems for evolutionary analysis. In: Barrett SCH (ed.) Evolution and Function of Heterostyly. Berlin, Springer-Verlag. p. 1-29.

Barrett SCH, Hardler LD, Cole WW. 2004. Correlated evolution of floral morphology and mating type frequencies in a sexually polymorphic plant. Evolution 58: 964-975.

Carmo RM, Franceschinelli EV, Silveira FA. 2004. Introduced honeybees (Apis mellifera) reduce pollination success without affecting the floral resource taken by native pollinators. Biotropica 36: 371-376.

Delpetre PG, Smith LB, Klein RM. 2005. Rubiaceae. In: Reis A. (ed.) Flora Ilustrada Catarinense. I Parte - As Plantas/ Monografia. Itajaí, Herbário Barbosa Rodrigues. p. 542-549.

Dick CW. 2001. Genetic rescue of a remnant tropical tree by an alien pollinator. Proceedings of the Royal Society of London.Biological Sciences 268: 2391-2397.

Dulberger R. 1992. Floral polymorphisms and their functional significance in the heterostylous syndrome. In: Barrett SCH. (ed.) Evolution and Function of Heterostyly. Berlin, Springer-Verlag. p. 41-84.

EMBRAPA-CNPGC - Empresa Brasileira de Pesquisa Agropecuária Gado de corte. 1985. Boletim Agrometeorológico. Campo Grande, EMBRAPA.

Faria RR, Ferrero V, Navarro L, Araujo AC. 2012. Flexible mating system in distylous populations of Psychotria carthagenensis Jacq. (Rubiaceae) in Brazilian Cerrado. Plant Systematics and Evolution 298: 619-627.

Felfili JM, Mendonça RC, Nóbrega MGG, Fagg CW, Sevilha AC, Silva MA. 2001. Flora fanerogâmica das matas ciliares do Brasil central. In: Ribeiro JF, Fonseca CEL, Sousa-Silva JC. (eds.) Cerrado: caracterização recuperação de matas ciliares. Planaltina, EMBRAPA. p. 195-263.

Freitas L. 2014. Concepts of pollinator performance: is a simple aproach necessary to achieve a standardized terminology? Brazilian Journal of Botany 36: 3-8.

Fumero-Cabán, JJ, Meléndez-Ackerman EJ. 2007. Relative pollination effectiveness of floral visitors of Pitcairnia angustifolia (Bromeliaceae). American Journal of Botany 94: 419-424.

Ganders FR. 1979. The biology of heterostyly. New Zealand Journal Botany 17: 607-635.

Goulson D. 2003. Effects of introduced bees on native ecosystems. Annual Review of Ecology and Systematics 34: 1-26.
Gross P. 2005. Pollination effectiveness. In: Dafni A, Kevan PG, Husband BC. (eds.) Practical Pollination Biology. Cambridge, Enviroquest Ltd.

Gross CL, Mackay D. 1998. Honeybees reduce fitness in the pioneer shrub Melastoma affine (Melastomataceae). Biological Conservation 86: $169-178$

Herrera CM. 1987. Components of pollination "quality": comparative analysis of a diverse insects assemblage. Oikos 50: 79-90.

Herrera CM. 1989. Pollinator abundance, morphology, and visitation rate: analysis of the "quantity" component in a plant-pollinator system. Oecologia 80: 241-248.

Huryn VMB. 1997. Ecological impacts of introduced honey bees. The Quarterly Review of Biology 72: 275-297.

Ivey CT, Martínez P, Wyatt R. 2003. Variation in pollinator effectiveness in swamp milkweed, Asclepias incarnata (Apocynaceae). American Journal of Botany 90: 214-225.

Kenta T, Inari N, Nagamitsu T, Goka K, Hiura T. 2007. Commercialized European bumblebee can cause pollination disturbance: an experiment on seven native plant species in Japan. Biological Conservation 134: 298-309.

Köppen W. 1948. Climatología. Pánuco, Editora Fondo de Cultura Econômica.

Lloyd DG, Webb CJ. 1992. The selection of heterostyly. In: Barrett SCH. (ed.) Evolution and Function of Heterostyly. Berlin, Springer-Verlag. p. 179-207.

Madjidian JA, Morales CL, Smith HG. 2008. Displacement of a native by an alien bumblebee: lower pollinator efficiency overcome by overwhelmingly higher visitation frequency. Oecologia 156: 835-845.

Massinga PH, Johnson SD, Harder LD. 2005. Heteromorphic incompatibility and efficiency of pollination in two distylous Pentanisia species (Rubiaceae). Annals of Botany 95: 389-399.

Moragues E, Traveset A. 2005. Effect of Carpobrotus spp. on the pollination success of native plant species of the Balearic Islands. Biological Conservation 122: 611-619.

Nadia TL, Machado IC, Lopes AV. 2007. Fenologia reprodutiva e sistema de polinização de Ziziphus joazeiro Mart. (Rhamnaceae): atuação de Apis mellifera e de visitantes florais autóctones como polinizadores. Acta Botanica Brasilica 21: 835-845.

Olesen JM, Eskildsen LI, Venkatasamy S. 2002. Invasion of pollination networks on oceanic islands: importance of invader complexes and endemic super generalists. Diversity and Distributions 8: 181-192.

Ornelas JF, Jiménez L, González C, Hernandéz A. 2004. Reproductive ecology of distylous Paulicorea padifolia (Rubiaceae) in a tropical montane cloud forest. I. Hummingbirds' effectiveness as pollen vectors. American Journal of Botany 91: 1052-1060.

Paini DR. 2004. Impact of the introduced honey bee (Apis mellifera) (Hymenoptera: Apidae) on native bees: A review. Austral Ecology 29: 399-407.

Pott A, Pott VJ. 1994. Plantas do Pantanal. Corumbá, Embrapa.

Santos GMM, Aguiar CML, Genini J, Martins CF, Zanella FCV, Mello MAR. 2012. Invasive Africanized honeybees change the structure of native pollination networks in Brazil. Biological Invasions 14: 2369-2378.

Sobrevilla C, Arroyo MTK. 1982. Breeding systems in a montane tropical cloud forest in Venezuela. Plant Systematics and Evolution 140: 19-37.

Sokal, RR, Rolf JF. 1995. Biometry: The principles and practice of statistics in biological research. New York, W.H. Freeman.

Stebbins GL. 1970. Adaptive radiation of reproductive characteristics in angiosperms. I. Pollination mechanisms. Annual Review of Ecology and Systematics 1: 307-326.

Thompson JD, Barrett SCH, Baker AM, 2003. Frequency-dependent variation in reproductive success in Narcissus: implications for the maintenance of stigma-height dimorphism. Proceedings of Royal Society B: Biological Sciences 270: 949-953.

Wilms W, Imperatriz-Fonseca VL, Eengels W. 1996. Resource partitioning between highly eusocial bees and possible impact of the introduced Africanized honey bee on native stingless bees in the Brazilian Atlantic rain forest. Studies on Neotropical Fauna and Environment 31: 137-151. 